\title{
openheart Markedly increased intake of refined carbohydrates and sugar is associated with the rise of coronary heart disease and diabetes among the Alaskan Inuit
}

James J DiNicolantonio, James O'Keefe

To cite: DiNicolantonio JJ, O'Keefe J. Markedly increased intake of refined carbohydrates and sugar is associated with the rise of coronary heart disease and diabetes among the Alaskan Inuit. Open Heart 2017;4:e000673. doi:10.1136/ openhrt-2017-000673

Accepted 19 November 2017

CrossMark

Saint Lukes Mid America Heart Institute, University of MissouriKansas City, Kansas City, Missouri, USA

Correspondence to Dr James J DiNicolantonio; jjdinicol@gmail.com
In a recent issue of the journal, DiNicolantonio published evidence suggesting that an increase in the intake of refined carbohydrates and sugar paralleled the rise in the incidence of atherosclerotic disease in the Greenland Inuit. ${ }^{1}$ Thus, we sought to ascertain if a similar trend occurred in Alaskan Inuit by reviewing the literature as far back as the 1950s. Because of their relative isolation prior to the 1950 s, studying the dietary changes that occurred in the Alaskan Inuit in the following decades can provide great insight into potential factors that may have caused a decline in their health.

The Inuit are said to be descendants of the Thule people who originally came to North America 3000 years ago from Asia through Siberia and the Bering Strait. ${ }^{2}$ The Inuit then travelled from Northwest Alaska towards Canada and Greenland and also south towards inland regions of Alaska. This paper will discuss Alaskan natives in general and Alaskan Inuit in particular.

In 1972, Dr Sheldon A Feldman, MD, and colleagues published a study on the Inuit living on Alaska's North Slope (Point Hope). During the early 1970s, the Eskimos of Point Hope (known as the 'Tigara' people) were one of the few Inuit villages that still subsisted on whale and seal meat and blubber. Only two other villages at the time along Alaska's North Slope continued the traditional hunting of whales using harpoons during the spring months. In the spring and early summer, these North Slope Alaskan Inuit mainly relied on catching and eating seal, walrus and fish. In the summer, the main dietary staple was caribou, and in winter, they would occasionally catch and eat polar bear. The consumption of grains and other carbohydrates was low due to the high cost of their import. ${ }^{2}$

It has been estimated that the Alaskan Inuit consumed around 3000 calories per day, with $50 \%$ of their calories coming from fat, $30 \%-35 \%$ from protein and $15 \%-20 \%$ from carbohydrate. The estimated intake of carbohydrate $(15 \%-20 \%$ of total calories) was largely estimated from glycogen stores in the meat however, and it was not known in 1972 that postmortem glycogen rapidly degrades to lactic acid. Thus, since most of the estimated carbohydrate intake was said to come from glycogen in the meat (which would have been degraded prior to consumption), the traditional Alaskan Inuit would have consumed less than $10 \%$ of their total calories as exogenous carbohydrate with virtually no consumption of refined sugar.

Indeed, the dietary pattern of the Alaskan Inuit was documented by Feldman in the following, 'Grain products were scarce, and while sucrose was not unknown, the average adult ingested less than 30 grams a day of sucrose primarily as sweetening for tea or coffee'. Thus, the traditional Alaskan Inuit diet was very low in refined carbohydrates and sugar. ${ }^{2}$

In 1972, Feldman and colleagues, based on previous observations and postmortem examinations from others, noted signs of atherosclerosis in the traditional Alaskan Inuit. However, there was little if any clinical manifestations of cardiovascular disease, 'The Eskimos' vasculature, indeed, showed some degree of atherosclerotic changes, but the severity was usually not enough to produce clinically recognizable symptoms and signs...Thus, atherosclerosis indeed exists in Eskimos, but is less severe and only rarely produces clinical manifestations and fatal complications. In contrast, in U.S. whites...they are suffering from a high incidence of atherosclerotic cardiovascular disease'.?

In summary, clinical symptoms of atherosclerotic disease such as angina as well as clinical manifestations of heart disease were extremely rare in the traditional Alaskan 
Point Hope Inuit, which was in contrast to what was occurring in the USA at the time. ${ }^{2}$

\section{DYSLIPIDAEMIA}

With westernisation however came an increase in the intake of refined carbohydrates and sugar in the Alaskan Inuit. Indeed, compared with the Inuit of Point Hope, the Inuit living in a boarding high school consumed more carbohydrates ( $48 \%$ vs $10 \%$ of total calories), less fat (39\% vs $55 \%$ of total calories) and less protein $(14 \%$ vs $35 \%$ of total calories). ${ }^{2}$

This increase in the intake of carbohydrate appears to have contributed to dyslipidaemia in the Alaskan Inuit. Indeed, the average serum triglyceride level of the Point Hope Inuit was only $69 \mathrm{mg} / \mathrm{dL}$. However, the triglyceride levels among boarding school Inuit were $124 \mathrm{mg} / \mathrm{dL}$ and $101 \mathrm{mg} / \mathrm{dL}$, which represented increases of $80 \%$ and $46 \%$ in the men and women, respectively. ${ }^{2}$ Very low density lipoprotein (VLDL) levels of the Alaskan Inuit were also extremely low $(<35 \mathrm{mg} / \mathrm{dL})$ or about two to six times lower than levels found in US whites at the time (60-200 mg/dL). ${ }^{2}$

Feldman $e t a l^{2}$ suggested that the increase in the triglyceride levels in the boarding school Inuit was likely due to 'A diet rich in carbohydrates, particularly simple sugars, which elevates serum triglyceride levels due to the increased availability of triglyceride precursors such as acetyl CoA and glycerol-6-phosphate which favors a net synthesis of triglycerides. The reverse conditions were true for Point Hope Eskimos. Their lipogenesis must be inhibited by the relative scarcity of these precursors due to a low carbohydrate intake. Moreover, it would be expected that Point Hope Eskimos would have low insulin values...' In other words, the high carbohydrate diet and subsequent higher insulin levels were thought to be likely drivers of higher triglyceride levels in Alaskan Inuit consuming a more Western diet.

\section{CARDIOVASCULAR DISEASE}

Gottman discovered the true incidence of cardiovascular disease in Alaskan natives by performing a large postmortem study between 1956 and 1958. He found that death due to acquired cardiovascular disease at autopsy was just $5.8 \% .^{23}$ Another large autopsy study conducted during the same time period (1955-1959) in the USA found that $30.6 \%$ of all deaths were due to morphological evidence of atherosclerotic catastrophe in the heart, aorta or brain. ${ }^{4}$ In other words, the Alaskan Inuit apparently had a fivefold lower cardiovascular mortality rate versus those in the USA at the time. Another autopsy study, this time spanning the subsequent decade (ie, 1959-1968), found a prevalence of cardiovascular disease of only $10.3 \%$ in Alaskan natives. ${ }^{2}$ Thus, even during the 1960s, Alaskan natives had a threefold lower incidence of death due to cardiovascular disease compared with that of the USA.
The incidence of ischaemic heart disease based on autopsy studies was just $1 \%$ in Alaskan Inuit (1956$1958)^{23}$ versus $18.44 \%(1950-1955)^{5}$ in the USA and just $2 \%$ in Alaskan Inuit (1959-1968) but 30\% in the USA (1964). ${ }^{2} 67$ Thus, the data suggest that the traditional Alaskan Inuit (based on autopsy studies from the 1950s and $1960 \mathrm{~s}$ ) had around $1 / 15$ th to $1 / 18$ th the rate of death from ischaemic heart disease compared with the USA at the time.

The Alaskan Inuit also had a much milder form of atherosclerosis compared with that found in the Western world. Feldman $e t a l^{2}$ noted, 'These postmortem studies, however, also disclosed the fact that about $10 \%$ of the Eskimo population did have a significant degree of atherosclerosis. Roentgenological (x-ray) evidence of atherosclerosis of the aortic arch was detected by Rodahl in three out of nine Eskimos over 47 years of age (33\%). Therefore, the Eskimos did develop atherosclerosis which was mild in degree, of limited clinical significance, and certainly did not account for one of the major causes of death among them'.

It is sometimes argued that because Eskimos usually die younger than those in the Western world (due to infections, accidents or harsh weather), this may skew the results in favour of the Eskimos. However, comparing the incidence of atherosclerosis in Alaskan Inuit who are over 47 years old $(33 \%)$ with data from the International Atherosclerosis Project (1960-1965), an autopsy study of men encompassing 23207 sets of coronary arteries and aorta from 14 countries found an incidence of atherosclerosis of $71 \%-82 \%$ in blacks/ Caucasians aged 45-54years old living in New Orleans. ${ }^{8}$ Cases with fibrous atherosclerotic plaques for all 14 countries studied were 58\%-96\%.

In summary, based on X-ray exams, older Alaskan natives had about one-half to one-third the rate of atherosclerosis compared with 14 other more westernised populations on autopsy. Autopsy studies in the mid-to-late 1950s in Alaskan Inuit showed around one-fifth the rate of death from cardiovascular disease (5.8\%) as compared with those in the USA (30.6\%) during the same time period, and based on autopsy studies, the rate of death from ischaemic heart disease in Alaskan Inuit was around $1 / 18$ th that of the USA ( $1 \%$ vs $18.44 \%) .^{2}$ Future studies with a more robust design may be needed to more accurately confirm these findings.

The more current data in Alaska (1979-2002) looks more dismal compared with these earlier data. Based on death certificate data, "Alaska Natives were previously at a lower risk for death from CHD than were non-native Alaskans; however, this discrepancy has disappeared. Alaska Natives currently have a higher prevalence of numerous risk factors for coronary heart disease compared with non-native Alaskans'. ${ }^{9}$ Indeed, in the late 1970s, death due to heart disease in Alaskan natives was only about $20 \%$ lower versus US whites, and by the mid-1980s, the rates were nearly identical. ${ }^{10}$ Thus, Alaskan natives who had previously had 


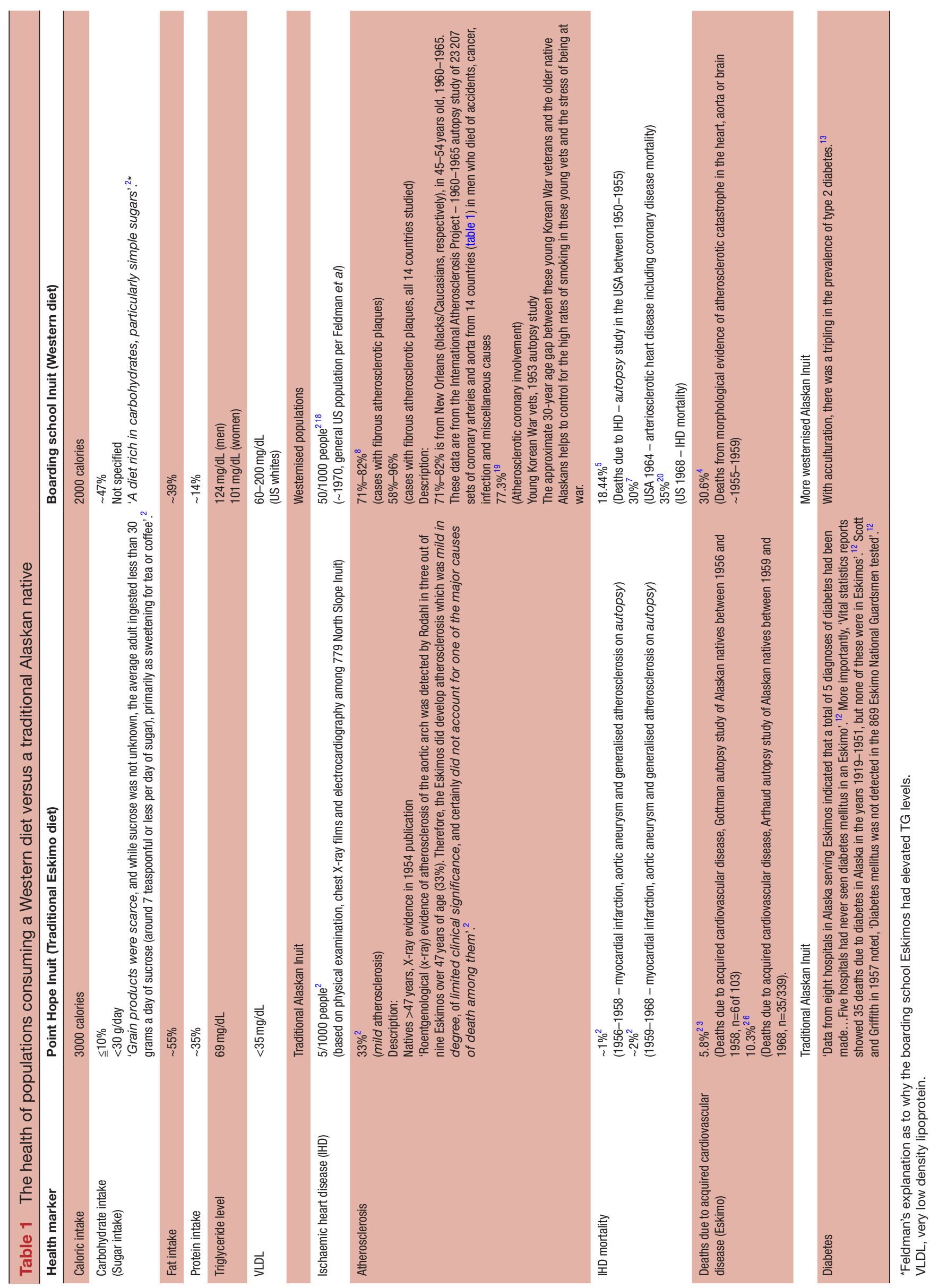


just $1 / 18$ th the rate of death due to ischaemic heart disease in the mid-1950s had an identical rate of heart disease mortality by the mid-1980s compared with the USA. Importantly, one of the major dietary changes that occurred in the mid-1950s in Alaskan Inuit was an increase in the intake of carbohydrates and simple sugars. $^{11}$

\section{DIABETES}

In the 1950s, only five diagnoses of diabetes had been made from eight hospitals serving Alaskan Inuit, 'Five hospitals had never seen diabetes mellitus in an Eskimo'. ${ }^{12}$ More importantly, 'Vital statistics reports showed 35 deaths due to diabetes in Alaska in the years 1919-1951, but none of these were in Eskimos'. ${ }^{12}$ In other words, prior to 1950 , diabetes was virtually non-existent in the Alaskan Inuit. Scott and Griffith in 1957 wrote, 'Diabetes mellitus was not detected in the 869 Eskimo National Guardsmen tested'. ${ }^{12}$ Thus, diabetes was apparently absent in Alaskan Inuit even up to 1957. Interestingly, the intake of carbohydrates among Alaskan Inuit increased by around 50\% from 1957 to $1965,{ }^{11}$ and by the early 1970 s, the rate of diabetes in Alaskan natives had tripled. ${ }^{13}$ This suggests that the increase in the intake of refined carbohydrates in the Alaskan Inuit may have contributed to their rise in diabetes. These dietary changes and the associated negative health consequences are summarised in table 1 .

\section{CONCLUSION}

The traditional Alaskan Inuit diet consisted of less 10\% of total calories as carbohydrate. Even with the introduction of sugar, early on, the total intake would have been less than $5 \%$ of total calories. Nowadays, however, sugar-sweetened beverages are the main sources of calories in Alaskan natives ${ }^{14}$ with added sugars making up $20 \%$ of the total caloric intake compared with $14 \%$ of calories consumed in general US population. ${ }^{15}{ }^{16}$ Importantly, a higher intake of low-nutrient-dense carbohydrates is associated with a higher rate of type 2 diabetes in Alaskan natives. ${ }^{17}$ The evidence suggests that an increase in the intake of refined carbohydrates and sugar may have contributed to the health decline of the Alaskan Inuit. Thus, a reduction in the intake of refined carbohydrates and sugar may drastically improve the health of Alaskan natives.

Contributors JJD performed the literature search and wrote the manuscript. J0 reviewed and edited the final manuscript.
Competing interests JJD is the author of The Salt Fix and has a website www. thesaltfix.com.

Provenance and peer review Not commissioned; internally peer reviewed.

Open Access This is an Open Access article distributed in accordance with the Creative Commons Attribution Non Commercial (CC BY-NC 4.0) license, which permits others to distribute, remix, adapt, build upon this work non-commercially, and license their derivative works on different terms, provided the original work is properly cited and the use is non-commercial. See: http://creativecommons.org/ licenses/by-nc/4.0/

(c) Article author(s) (or their employer(s) unless otherwise stated in the text of the article) 2017. All rights reserved. No commercial use is permitted unless otherwise expressly granted.

\section{REFERENCES}

1. DiNicolantonio JJ. Increase in the intake of refined carbohydrates and sugar may have led to the health decline of the Greenland Eskimos. Open Heart 2016;3:e000444.

2. Feldman SA, Ho KJ, Lewis LA, et al. Lipid and cholesterol metabolism in Alaskan Arctic Eskimos. Arch Pathol 1972;94:42-58.

3. Gottmann AW. A report of one hundred three autopsies on Alaskan natives. Arch Pathol 1960;70:117-24.

4. Roberts JC, Moses C, Wilkins RH. Autopsy studies in Atherosclerosis: I. Distribution and severity of Atherosclerosis in patients dying without morphologic evidence of Atherosclerotic Catastrophe. Circulation 1959;20:511-9.

5. Parrish HM. Epidemiology of ischemic heart disease among white males. II. Autopsy incidence of ischemic heart disease and autopsy prevalence of coronary atherosclerosis. J Chronic Dis 1961;14:326-38.

6. Arthaud JB. Cause of death in 339 Alaskan natives as determined by autopsy. Arch Pathol 1970;90:433-8.

7. Population. http://www2.census.gov/library/publications/1967/ compendia/statab/88ed/1967-02.pdf

8. Tejada C, Strong JP, Montenegro MR, et al. Distribution of coronary and aortic atherosclerosis by geographic location, race, and sex. Lab Invest 1968;18:509-26.

9. Fodor JG, Helis E, Yazdekhasti N, et al. Fishing 'for the origins of the' 'Eskimos and heart disease' story: facts or wishful thinking? Can J Cardiol 2014;30:864-8.

10. Day GE, Lanier AP. Alaska native mortality, 1979-1998. Public Health Rep 2003;118:518-30.

11. Bang G, Kristoffersen T. Dental caries and diet in an Alaskan Eskimo population. Scand J Dent Res 1972;80:440-4.

12. Scott EM, Griffith IV. Diabetes mellitus in Eskimos. Metabolism 1957;6:320-5.

13. Schaefer O. When The Eskimo Comes To Town. Nutr Today 1971;6:8-16.

14. Sharma S, Mead E, Simeon D, et al. Dietary adequacy among rural Yup'ik women in western Alaska. J Am Coll Nutr 2015;34:65-72.

15. ANTHC. http://anthctoday.org/epicenter/publications/otherReports/ traditional_diet.pdf

16. Drewnowski A, Rehm CD. Consumption of added sugars among US children and adults by food purchase location and food source. Am J Clin Nutr 2014;100:901-7.

17. Murphy NJ, Schraer CD, Thiele MC, et al. Dietary change and obesity associated with glucose intolerance in Alaska Natives. J Am Diet Assoc 1995;95:676-82.

18. Coronary Heart Disease in Adults, United States, 1960-1962, National Health Survey, Vital and Health Statistics, series 2, No. 10. US Dept of Health, Education, and Welfare, PublicHealth Service 1965.

19. Joseph A, Ackerman D, Talley JD, et al. Manifestations of coronary atherosclerosis in young trauma victims--an autopsy study. J Am Coll Cardiol 1993;22:459-67.

20. U.S. Bureau of Census Statistical Abstract. Bureau of Census, 1970, 1970:58. http://www2.census.gov/library/publications/1971/ compendia/statab/92ed/1971-02.pdf 